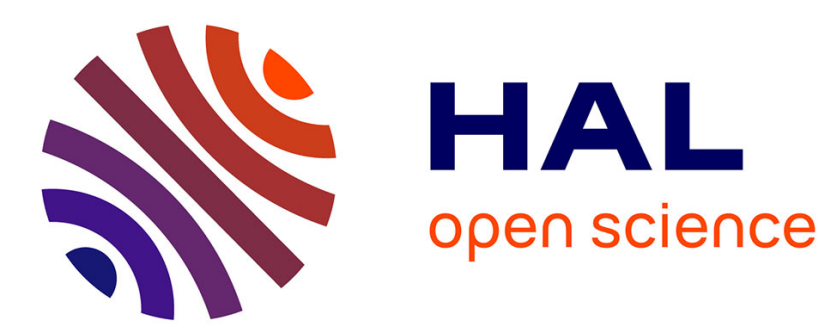

\title{
Unexpected seedling growth in the understory of post-agricultural forests from Eastern Canada
}

d'Orangeville, Bouchard, Cogliastro

\section{To cite this version:}

d'Orangeville, Bouchard, Cogliastro. Unexpected seedling growth in the understory of postagricultural forests from Eastern Canada. Annals of Forest Science, 2011, 68 (4), pp.759-769. 10.1007/s13595-011-0073-3 . hal-00930806

\section{HAL Id: hal-00930806 https://hal.science/hal-00930806}

Submitted on 1 Jan 2011

HAL is a multi-disciplinary open access archive for the deposit and dissemination of scientific research documents, whether they are published or not. The documents may come from teaching and research institutions in France or abroad, or from public or private research centers.
L'archive ouverte pluridisciplinaire HAL, est destinée au dépôt et à la diffusion de documents scientifiques de niveau recherche, publiés ou non, émanant des établissements d'enseignement et de recherche français ou étrangers, des laboratoires publics ou privés. 


\title{
Unexpected seedling growth in the understory of post-agricultural forests from Eastern Canada
}

\author{
Loïc D'Orangeville • André Bouchard • Alain Cogliastro
}

Received: 13 March 2010 / Accepted: 8 December 2010/Published online: 26 May 2011

(C) INRA and Springer Science+Business Media B.V. 2011

\begin{abstract}
- Introduction The agricultural landscape in Eastern Canada has drastically changed in the last decades. Whilst certain forest communities are disappearing, post-agricultural forests are emerging from old fields colonized by fast-growing tree species.

- Objective The objective of this study was to assess the seedling establishment and growth patterns of deciduous angiosperms in regenerating 14 of these aggrading forests.

- Results Red maple and black cherry showed clear temporal windows of establishment about 10-20 years following old field colonization by trees, contrary to sugar maple, white and green ash. Also, height growth rates of red maple and phenotypic plasticity of sugar maple did not correspond to their shade tolerance ranks. In general, low growth rates were found for all tree species, suggesting that the presence of adverse conditions could slow down the domination of postagricultural stands by later successional species.

- Conclusions These results underline the specificity of postagricultural contexts and militate for the implementation of
\end{abstract}

Handling Editor: Douglass Jacobs

André Bouchard deceased during the revision process.

L. D’Orangeville · A. Bouchard · A. Cogliastro

Institut de recherche en biologie végétale (IRBV),

Center for Forest Research (CFR), Université de Montréal,

4101 Sherbrooke E.,

Montréal, QC, Canada H1X 2B2

Present Address:

L. D’Orangeville $(\bowtie)$

Department of Natural Resource Sciences, McGill University,

21,111 Lakeshore Rd.,

Sainte-Anne-de-Bellevue, QC, Canada H9X 3V9

e-mail: loicdorangeville@gmail.com adapted management strategies that could help in reversing the trend of decreasing mature forests worldwide.

Keywords Seedling growth . Phenotypic plasticity . Post-agricultural forest $\cdot$ Regeneration $\cdot$ Shade tolerance

\section{Introduction}

Following biophysical, anthropological and technological transformations, agricultural landscapes in Eastern Canada have drastically changed in the last decades. Numerous impacts have been observed including significant change in species relative abundances. For example, intensive cattle grazing has played a significant role in the appearance of white cedar stands (Thuja occidentalis L.) in the deciduous forests of southern Quebec (De Blois and Bouchard 1995). Whilst certain forest communities are disappearing, old fields are becoming increasingly colonized and dominated by fast-growing tree species, thus becoming postagricultural forests (Flinn and Vellend 2005). In southern Quebec, these young aggrading forests are generally dominated by trembling aspen (Populus tremuloides Michx.) or grey birch (Betula populifolia Marsh.). Many stakeholders today are hoping that these new forests could someday produce the goods and services historically provided by the lost primary forests.

Using the current models of forest succession would lead us to predict the plant succession in post-agricultural forests in terms of species shade tolerance. The general model of shade tolerance that prevails today classifies the species according to their carbon assimilation strategy (Bazzaz 1979; Givnish 1988). According to this model, phenotypic plasticity and low-light height growth rate explain the shade tolerance of a given species (Canham 1988). However, a 
number of studies on shade tolerance in tropical and temperate regions suggest otherwise: shade tolerance, rather than being determined by the carbon assimilation capacity, could be defined by the capacity for a tree to retain its biomass and energy through traits such as low respiration rate or high leaf longevity (Kitajima 1994; Reich et al. 2003). Thus, as some studies already suggested, this theory underlies that the characteristics maximizing carbon gain in a light-limited environment, such as phenotypic plasticity or height growth rate, are not necessarily determining the shade tolerance of a species (Beaudet and Messier 1998; Paquette et al. 2007a). It is clear, however, that these characteristics still affect the successional dynamic of a forest ecosystem. The conditions associated with a successful dispersal of the seed to the old field, germination of the seed, survival and growth of the seedling change with time during an old field succession. Invasion and establishment are functions of the availability of adequate conditions and could depend on the removal of a barrier that had previously excluded a species from a site. Therefore, succession largely depends on the type of barrier and the availability of adequate conditions in space and time. Such conditions were formalized by some authors in the concept of a "window" (see Rankin and Pickett 1989) which represents regeneration opportunities and probabilities.

A previous study showed the major role of soil and landscape agricultural footprint on the successional trajectory of the stands, which could lead to a weakened resilience capacity (D'Orangeville et al. 2008). Using abundance and distribution data, it was concluded that seedling composition and abundance were insufficient to ensure the future of these stands. To follow up on these results, our main objectives in this study were to (1) detect the presence of temporal establishment windows for dominant species at the seedling stage and (2) compare growth and phenotypic plasticity of the species in relation with their known shade tolerance and growing strategies. We studied species in the understory that are predicted to constitute the next generation of dominant canopy trees, i.e. sugar and red maple (Acer saccharum Marsh. and Acer rubrum L.), white and green ash (Fraxinus americana L. and Fraxinus pennsylvanica Marsh.) and black cherry (Prunus serotina Ehrh.; see D'Orangeville et al. 2008). On a scale of 0 (no tolerance) to 5 (maximal tolerance), sugar maple is very shade-tolerant $(4.8 \pm 0.11)$, followed by red maple (3.4 \pm 0.23$)$, green ash $(3.1 \pm 0.11)$, and shadeintolerant white ash $(2.5 \pm 0.21)$ and black cherry $(2.5 \pm$ 0.34; Niinemets and Valladares 2006). Three major parameters of secondary succession were measured: (1) the time frame of species establishment, (2) the height growth rate and (3) the phenotypic plasticity to light and neighbouring plant cover.

\section{Materials and methods}

\subsection{Study region}

The study took place in three regional county municipalities of the southernmost part of the Province of Québec (Canada)-Haut-Saint-Laurent $\left(45^{\circ} 7^{\prime} \mathrm{N}, 7^{\circ} 59^{\prime} \mathrm{W}\right)$, Acton $\left(45^{\circ} 40^{\prime} \mathrm{N}, 72^{\circ} 33^{\prime} \mathrm{W}\right)$ and Brome-Missisquoi $\left(45^{\circ} 10^{\prime} \mathrm{N}\right.$, $72^{\circ} 46^{\prime} \mathrm{W}$ ) - to reflect a gradient of agricultural intensity and forested cover. Their respective forest cover represents $28 \%, 41 \%$ and $59 \%$ of the total surface area, respectively (Soucy-Gonthier et al. 2003). The region is part of the deciduous forest region of the Great Lakes and StLawrence River system (Rowe 1972). Haut-Saint-Laurent is located in the maple-bitternut hickory (A. saccharumCarya cordiformis [Wangenh.] K. Koch) bioclimatic domain, whereas Acton and Brome-Missisquoi are located in the maple-basswood (A. saccharum-Tilia Americana L.) bioclimatic domain (Grandtner 1966). Climate is relatively homogenous between the three municipalities (Table 1). The Haut-Saint-Laurent area is part of the St-Lawrence River bottomlands, a vast and flat marine plain of clay deposits heavily cultivated. Ridges and mounds of morainic deposits topped by brown forest soils can be found (Laplante 1959). Acton and Brome-Missisquoi areas have a high diversity of surface deposits, with varying land uses, where old fields bound agricultural and forested

Table 1 Climate means of the studied municipalities (Environment Canada 2004)

\begin{tabular}{llllll}
\hline RCM & Weather station (coordinates) & $T_{\mathrm{AN}}\left({ }^{\circ} \mathrm{C}\right)$ & $T_{\mathrm{SE}}\left({ }^{\circ} \mathrm{C}\right)$ & $R_{\mathrm{AN}}(\mathrm{mm})$ & Degree days $>5^{\circ} \mathrm{C}$ \\
\hline Haut-St-Laurent & St-Anicet $\left(45^{\circ} 7^{\prime} \mathrm{N}, 74^{\circ} 21^{\prime} \mathrm{W}\right)$ & 6.5 & $\begin{array}{l}\text { January: }-9.6 \\
\text { July: } 20.9\end{array}$ & 989.2 (rain: 813$)$ & $2,136.2$ \\
Acton & St-Hyacinthe $2\left(45^{\circ} 34^{\prime} \mathrm{N}, 72^{\circ} 55^{\prime} \mathrm{W}\right)$ & 6.2 & $\begin{array}{l}\text { January: }-10.5 \\
\text { July: } 21.1\end{array}$ & $1,057.9$ (rain: 856$)$ & $2,131.4$ \\
Brome-Missisquoi & Brome $\left(45^{\circ} 10^{\prime} \mathrm{N}, 72^{\circ} 34^{\prime} \mathrm{W}\right)$ & 5.3 & $\begin{array}{l}\text { January: }-10.5 \\
\text { July: } 19.4\end{array}$ & $1,266.7$ (rain: 994$)$ & $1,872.7$
\end{tabular}

$T_{\mathrm{AN}}$ mean annual temperature, $T_{\mathrm{SE}}$ mean seasonal temperature, $R_{\mathrm{AN}}$ mean annual precipitation. 
areas. Mesic sites are generally dominated by sugar maple, along with bitternut hickory or American beech (Fagus grandifolia Ehrh.). However, an increasing proportion of sites presenting various degrees of disturbance are colonized by red maple, grey birch and trembling aspen (Meilleur et al. 1994).

\subsection{Stand sampling}

Using criteria acquired from provincial forest maps, we limited our sampling to sites of good to imperfect drainage, low slope gradients $(<4 \%)$ and soil depth $>25 \mathrm{~cm}$. Fourteen post-agricultural stands were sampled in 2004 and 2005 using a systematic sampling protocol. Five stands were surveyed in each study region, except in Haut-SaintLaurent where one site was excluded because of unforeseen harvesting. Stand area ranged from 0.5 to 5 ha (Table 2). Stands are dominated by shade-intolerant species, mostly grey birch and trembling aspen, as well as bigtooth aspen (Populus grandidentata Michx.; see Table 3), although individuals of later successional species are often found in the canopy. Soil texture varies from sandy loam to clay loam, soil acidity varies from $\mathrm{pH}$ values of 4.5-7.6 (Table 2), and regeneration stocking is generally low (D'Orangeville et al. 2008). Four to six dominant trees were cored at their base on each site using an increment borer whilst avoiding veteran trees which could have been present when the properties were being farmed. Ring counts from tree cores allowed us to date the stands from the time since abandonment. Main canopy tree ages span from 12 to 50 years (Table 2). These numbers give a minimal estimation of the duration of secondary succession since agricultural abandonment because there is typically a delay between the point at which fields are abandoned and the period of tree invasion.

The number of transects and plots was proportional to the size of the stand, with two to four evenly distributed transects per site. Eight to 20 circular plots per site, spaced at $10-\mathrm{m}$ intervals along transects, were sampled, for a total of 147 plots distributed on 14 sites.

\subsection{Measurements}

Vegetation survey was done using plots of various radii according to plant forms and sizes. Herb strata were surveyed in $3.1-\mathrm{m}^{2}$ plots, seedlings with a diameter at breast height (DBH, $1.37 \mathrm{~m})<1 \mathrm{~cm}$ in $12.5-\mathrm{m}^{2}$ plots, small shrubs $(\mathrm{DBH}<10 \mathrm{~cm})$ and saplings $(\mathrm{DBH}<10 \mathrm{~cm})$ in 28.3$\mathrm{m}^{2}$ plots, and trees and shrubs $(\mathrm{DBH}>10 \mathrm{~cm})$ in $154-\mathrm{m}^{2}$ plots. Total understory cover and cover by morphological groups were visually estimated. The estimation, based on the vertical projection of the aerial parts of the plants on the ground, was made using a scale of plant cover: $5-15 \%, 15$ $25 \%, 25-50 \%, 50-75 \%$ and $>75 \%$ ground cover. Morpho-

Table 2 Characteristics of studied stands including basal area and regeneration density

\begin{tabular}{|c|c|c|c|c|c|c|c|}
\hline Stand name & $\operatorname{Age}^{\mathrm{a}}$ (years) & Size (ha) & Basal area ${ }^{\mathrm{b}}\left(\mathrm{m}^{2} / \mathrm{ha}\right)$ & Dominant species ${ }^{\mathrm{c}}$ & $\begin{array}{l}\text { Regeneration density } \\
(\mathrm{n} / \mathrm{ha})\end{array}$ & Soil $\mathrm{pH}^{\mathrm{e}}$ & Soil texture \\
\hline Piette-25 & 12 & 1.8 & 19.2 & Betula populifolia & 7,000 & 5.3 & Sandy loam \\
\hline Daudelin-21 & 16 & 0.9 & 26.0 & Betula populifolia & 10,500 & 4.6 & Loam \\
\hline Boissé-3 & 19 & 0.5 & 24.0 & Populus tremuloides & 6,000 & 5.0 & Loam \\
\hline Grenier-1 & 20 & 1.6 & 16.0 & Betula populifolia & 3,000 & 4.7 & Loam \\
\hline Germiquet-2 & 21 & 0.6 & 17.0 & Betula populifolia & 2,300 & 4.8 & Sandy loam \\
\hline Chicoine-15 & 21 & 0.7 & 14.0 & Populus tremuloides & 5,100 & 6.6 & Loam \\
\hline Lemaire-24 & 24 & 5.0 & 26.0 & Betula populifolia & 5,360 & 5.9 & Clay loam \\
\hline Grenier-9 & 26 & 0.6 & 10.7 & Populus tremuloides & 2,000 & 5.1 & Silt loam \\
\hline Croteau-6 & 28 & 0.7 & 16.8 & Betula populifolia & 5,300 & 4.5 & Loam \\
\hline Westover-26 & 28 & 0.9 & 24.0 & Betula populifolia & 7,600 & 6.2 & Loam \\
\hline Cormier-28 & 33 & 2.2 & 26.6 & Populus tremuloides & 12,900 & 5.5 & Loam \\
\hline Boyer-12 & 44 & 0.9 & 41.0 & Populus grandidentata & 26,700 & 5.9 & Sandy loam \\
\hline Pivin-18 & 47 & 0.8 & 21.5 & Populus tremuloides & 14,400 & 7.6 & Loam \\
\hline McNair-16 & 50 & 0.9 & 18.3 & Populus grandidentata & 9,300 & 7.2 & Silt loam \\
\hline
\end{tabular}

-Measured as time since tree establishment

${ }^{\mathrm{b}}$ Basal area includes trees, saplings and shrubs

${ }^{\mathrm{c}}$ Dominant tree species were chosen based on relative basal area

${ }^{\mathrm{d}}$ Regeneration density values represent the number of seedlings of diameter $<1 \mathrm{~cm}$ and height $>20 \mathrm{~cm}$ per hectare, all species combined

${ }^{\text {e }}$ Soil analysis methods are detailed in D'Orangeville et al. (2008) 


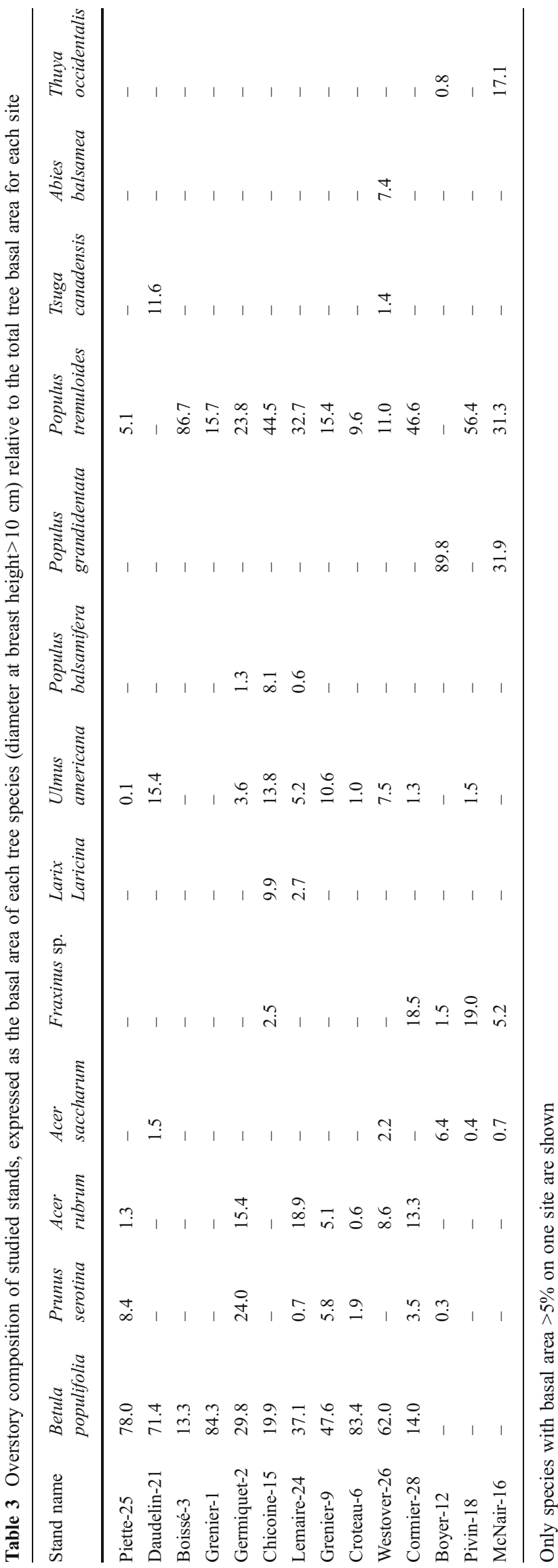

logical groups were defined as herbs, ligneous understory $(\mathrm{DBH}<1 \mathrm{~cm})$, ferns and Rubus species. Finally, the height of the most abundant understory morphological group (in cover) was measured as the highest point of the group's canopy. Species DBH were recorded for trees, saplings and shrubs. Height and cover were also noted for shrubs of $\mathrm{DBH}<10 \mathrm{~cm}$.

The BF2 type Sunshine Sensor (Delta-T Devices Ltd., Cambridge, UK) was used to measure diffuse available light (PAR; photosynthetically active radiation, micromoles per square metre per second). This device provides a good estimation of average seasonal available understory light under variable weather conditions, showing strong correlations ( $r>0.9$; see Paquette et al. 2007b) with common methods of seasonal PAR estimation such as the overcast method (Messier and Puttonen 1995) and the hemispherical image analysis (Englund et al. 2000), as well as high accuracy ( $95 \%$ confidence limits of $\pm 10 \mu \mathrm{mol} \mathrm{m} \mathrm{m}^{-2} \mathrm{~s}^{-1}$ ). Measures of in situ PAR were taken in the middle of each circular plot only once. For each plot, three instantaneous point measurements were taken at $0.5,1$ and $2 \mathrm{~m}$ above ground using a levelled tripod. Using radio communications, simultaneous measures of incident open-field PAR were taken with another BF2 in a nearby field. The ratio of understory PAR over open-field PAR is the PAR ratio, or ratio of available light in the understory. A single value is then obtained by taking the average of the PAR ratios at $0.5,1$ and $2 \mathrm{~m}$ above ground for each plot. All sites were measured at the end of July 2005. The main sampling effort was aimed at seedlings above $20 \mathrm{~cm}$ in height to measure morphological variables. At the end of the growing season, seedlings above $20 \mathrm{~cm}$ in height were counted and identified. In every sampling plot, when present, up to two individuals per species per height class $(20-30 \mathrm{~cm}, 31-$ $50,51-75,76-100,101-150$ and 151+) were randomly chosen and their whole aboveground biomass harvested for laboratory investigations, for a total of 614 individuals. Of all harvested tree species, bur oak (Quercus macrocarpa Michx.) and yellow birch (Betula alleghaniensis Britton) specimens were discarded because of their low numbers. We combined data for white and green ash because the two species are common to the study region and difficult to distinguish from one another at this stage. Aboveground parts of the selected seedlings were used for biomass partitioning and morphological measurements, including a sample of three to five leaves from each seedling, depending on its height, randomly taken on a height gradient and set aside in a herbarium for leaf area measurements.

\subsection{Laboratory analysis and data compilation}

All collected seedlings were dried at $40^{\circ} \mathrm{C}$ for a full week; divided into main stem, secondary stems (including 
petioles) and leaf components; and weighed in the laboratory. Individual leaf area of collected leaves was measured in the laboratory using an area meter (Delta- $\mathrm{T}$ area meter, Delta-T Devices Ltd.) and the samples weighed. Seedlings were aged by basal ring count in cross-sections at the root collar for every individual with binoculars $\times 40$. To measure environmental effects on growth, mean annual height growth rate was calculated as seedling height divided by its age. The last growing season was subtracted from seedling height because harvesting took place before the end of the growing season. To measure environmental effects on morphology, a series of ratios were calculated based on biomass and leaf area measures. Growth type index (GTI), i.e. the ratio of branch mass on trunk mass; slenderness $(H / D)$, i.e. height divided by diameter; leaf area ratio (LAR), i.e. total leaf area divided by total aboveground biomass; specific leaf area (SLA), i.e. the average of leaf area divided by leaf weight; and the ratio of nonphotosynthetic tissue to photosynthetic tissue (NPT/PT). The relationships measured in this study between seedling morphology, growth and environmental conditions could have been affected by browsing, a stochastic phenomenon having a major impact on regeneration in agro-forested areas (Côté et al. 2004).

\subsection{Statistical analysis}

Data were analysed using the seedling as the experimental unit. Mean annual height growth rates were compared using honestly significant difference (HSD) tests (TukeyKramer). Temporal windows of establishment for each species were compared using a similar Tukey-type test for medians based on a comparison of the mean ranks. Data normality and homoscedasticity were tested prior to the HSD tests. To analyse growth responses to environmental factors, we integrated each response variable, successively, in a linear regression model, as well as all environmental variables (light and plant abundance), and applied a forward selection at $p=0.10(9,999$ permutations $)$ to identify significant variables. A redundancy analysis (RDA) was then performed with the significant environmental variables and the response variables of all five species on standardised response matrices. RDA significance was tested using 9,999 permutations on a reduced model.

Seedling morphological response to its environment is known to be strongly dependent on the development stage (Coleman et al. 1994). To measure the direct effect of the environment on seedling morphology, seedling size had to be taken into account. Thus, we partitioned the variance of each response matrix (one per species) using partial RDAs on standardised response matrices. Two environmental matrices were built: matrix $A$ included seedling height and matrix $B$ included environmental factors, namely available light as well as neighbouring plant height, basal area and cover. Each fraction was tested using 9,999 permutations. In addition, correlations between morphology indices and species heights were completed and tested using 9,999 permutations. All multivariate analyses were generated using R Software (R Development Core Team 2009) and univariate analysis were done using JMP IN 7.0 (SAS Institute, Cary, USA).

With the seedling as the experimental unit, site conditions or environmental factors other than those measured were not explicitly accounted for in the study design and statistical analysis. Whilst this limits the inference that can be made on the findings, our results still highlight the importance of certain parameters that are specific to postagricultural contexts and help understand their successional dynamic in eastern North America.

\section{Results}

To compare growth and phenotypic plasticity among tree species, it was mandatory to ensure that stand structure and available light conditions were similar for each species. Results validate this premise (see Table 4, non-significant Tukey HSD tests). Mean levels of available light, i.e. the

Table 4 Forest structure and available light conditions associated with harvested seedlings (mean \pm confidence interval at $\alpha=0.05)$

\begin{tabular}{|c|c|c|c|c|}
\hline & Black cherry $(n=176)$ & Red maple $(n=86)$ & Sugar maple $(n=48)$ & Ash species $(n=286)$ \\
\hline Mean $\operatorname{PAR}^{\mathrm{a}}(\%)$ & $4.9 \pm 0.7$ & $5.9 \pm 1.1$ & $6.2 \pm 1.7$ & $4.9 \pm 0.9$ \\
\hline Total basal area $\left(\mathrm{m}^{2} / \mathrm{ha}\right)$ & $24.0 \pm 3.2$ & $21.5 \pm 3.0$ & $25.9 \pm 6.8$ & $25.2 \pm 2.6$ \\
\hline Shrub basal area $\left(\mathrm{m}^{2} / \mathrm{ha}\right)$ & $0.7 \pm 0.4$ & $1.0 \pm 1.0$ & $0.5 \pm 0.4$ & $0.9 \pm 0.5$ \\
\hline Total understory vegetation cover $(\%)$ & $78.4 \pm 4.5$ & $74.1 \pm 6.7$ & $75.4 \pm 9.6$ & $77.0 \pm 4.3$ \\
\hline Ferns cover $(\%)$ & $24.0 \pm 7.7$ & $18.0 \pm 7.2$ & $21.8 \pm 13.2$ & $29.6 \pm 8.2$ \\
\hline Ligneous cover $(\%)$ & $19.2 \pm 5.2$ & $10.9 \pm 3.1$ & $23.8 \pm 11.7$ & $17.1 \pm 5.0$ \\
\hline Herbaceous cover $(\%)$ & $33.7 \pm 8.2$ & $38.0 \pm 9.8$ & $25.6 \pm 10.9$ & $30.8 \pm 7.4$ \\
\hline Rubus cover $(\%)$ & $13.7 \pm 5.1$ & $14.2 \pm 4.9$ & $11.4 \pm 5.9$ & $11.0 \pm 3.6$ \\
\hline
\end{tabular}

${ }^{\mathrm{a}}$ Using Tukey HSD test, no significant differences were found between species at $p<0.05$ for any factor 
average of measures of light taken at $0.5,1$ and $2 \mathrm{~m}$, range between $4.0 \%$ and $7.9 \%$ of PAR $(95 \%$ confidence interval, CI), corresponding to basal areas between 32.7 and $18.5 \mathrm{~m}^{2} / \mathrm{ha}(95 \% \mathrm{CI})$, respectively. The understory vegetation covers approximately $75 \%$ of the forest floor, the remaining $25 \%$ being rocks, woody debris, bryophytes and bare soil. A large part of the understory vegetation is composed of herbs $(\sim 30 \%)$ and species of the genus Rubus ( $12 \%$; Table 4$)$, typical of young successional stands (Gill and Marks 1991).

\subsection{Seedling establishment}

Figure 1 shows relative abundances for seedlings of each species on a timescale beginning when the site was first colonized by trees (mainly birch and aspen). All species studied here produce good seed crops every 2 or 3 years
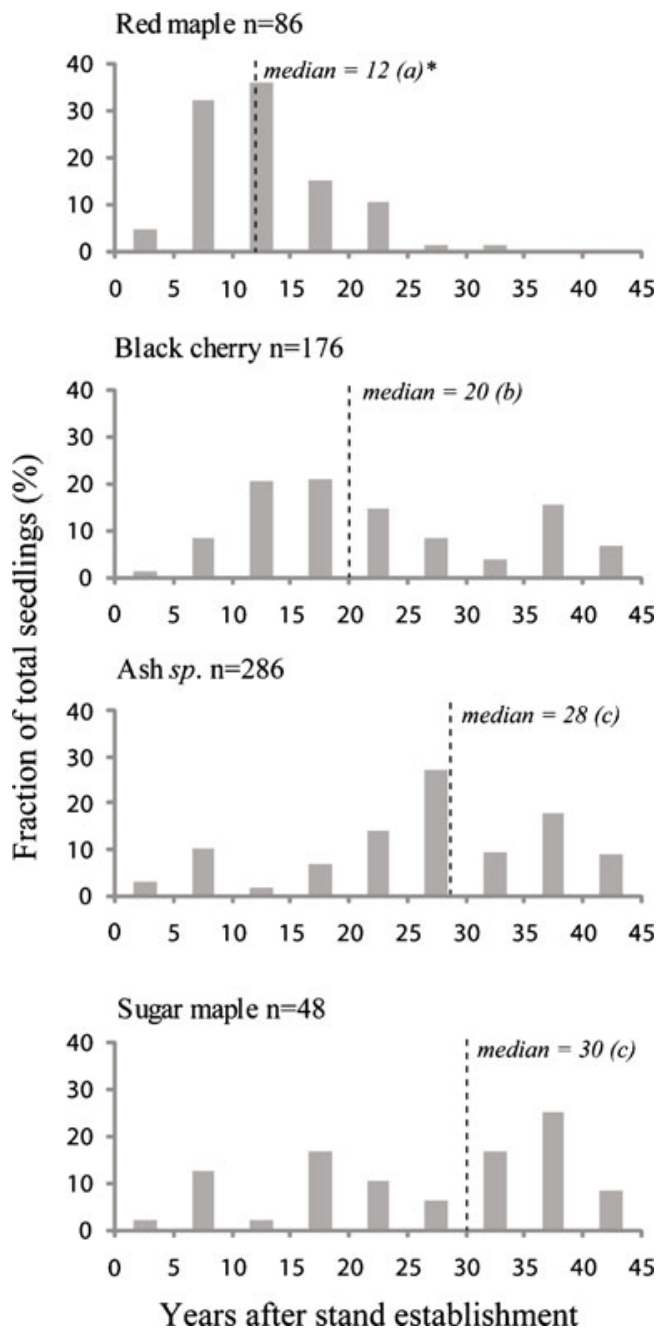

Fig. 1 Fraction of seedlings established as a function of time since stand initiation. *Letters express the results of multiple comparison analyses (medians not sharing the same letter are different) for a global type I error of 0.05 . Prior to multiple comparison analysis, a one-way ANOVA was performed, where $F=42.524$ and $p<0.0001$
(Burns et al. 1990). However, our results show for two out of four species a single abundance peak over more than 40 years of succession. Red maple establishment reaches its maximum abundance 12 years after the first pioneer trees and follows a normal distribution (Fig. 1). Black cherry reaches a first peak around 10-20 years for nine out of ten sampled sites, for a median age of 20 years since tree colonization. The tenth site shows a peak at around 40 years, which is a less representative value. Temporal windows of establishment for sugar maple and ash open statistically later than red maple and black cherry, with a median of $30(\mathrm{SD}=11.2)$ and 28 years $(\mathrm{SD}=10.7)$ after colonization by pioneer trees, respectively. The establishment window for sugar maple is vast and shows no single temporal peak (Fig. 1). In fact, seedling recruitment reaches peaks around 15-20 years, 30-35 years and, more commonly, 35-40 years after stand establishment. Ash seedlings present an intermediate picture, with a high peak of establishment 28 years after initiation of the stand, accompanied by much smaller peaks before and after (Fig. 1).

\subsection{Regeneration height growth rates}

Figure 2 shows mean annual height growth rates for seedlings since their germination. Large variation was observed for this variable. The varying ages and heights of seedlings, growing in various stands and environmental contexts, are likely responsible for this variation. In general, seedlings show slow height growth rates. Of the five species studied, black cherry is the fastest growing (10.0 $\mathrm{cm}$ year $\left.^{-1}, \mathrm{SD}=7.2\right)$ whilst being the most shadeintolerant. Its average height growth rate is statistically higher than that of sugar maple $\left(6.4 \mathrm{~cm}\right.$ year $\left.^{-1}, \mathrm{SD}=4.7\right)$ and ash (7.6 $\mathrm{cm} \mathrm{year}^{-1}, \mathrm{SD}=6.1$; Fig. 2). Sugar maple is the most shade-tolerant and has the lowest average height growth rate. Trends indicate that ash has an average height growth rate slightly superior to sugar maple and inferior to red maple $\left(8.1 \mathrm{~cm}^{\text {year }}{ }^{-1}, \mathrm{SD}=8.6\right)$, two species more shade-tolerant than ash.

To assess competition effects, we examined relationships between seedling height growth rates, light availability, and height, cover and basal area (when possible) of plant groups, such as herbaceous species or shrubs. The results suggest that tree species can be separated into three groups (Fig. 3). Red maple is the only species whose height growth seems favoured in conditions of higher light availability, whereas black cherry's growth seems to be unaffected by the observed range of available light. Highest height growth rates of ash and sugar maple are associated with low-light conditions.

However, each species presents distinctive characteristics. Height growth of black cherry, although not correlated with available understory light, is negatively 


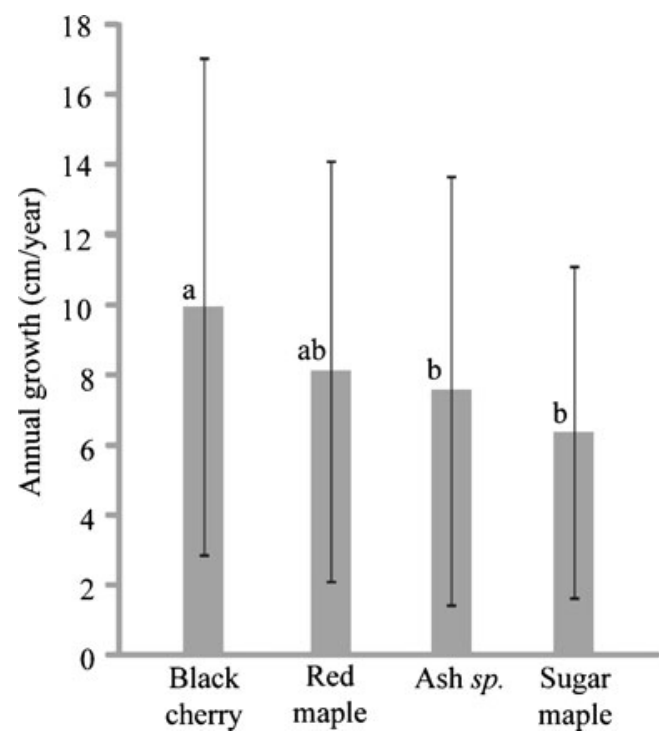

Fig. 2 Mean annual height growth rate of seedling species, as represented by seedling height divided by its age. ANOVA: $F=5.754$ and $p<0.001$. Error bars represent standard deviation from the mean. Letters express the results of multiple comparison analyses (means not sharing the same letter are different) for a global type I error of 0.05

correlated with the abundance of shrubs and ferns. At the same time, its height growth is positively associated with shade-intolerant herb and Rubus cover. In contrast with red maple, the highest height growth rates of sugar maple are associated with low-light contexts and a high understory cover. Furthermore, its growth seems positively correlated with the understory height. Just like sugar maple, ash growth is negatively correlated with available light. Figure 3 shows a positive association of ash seedlings with the presence of shrubs and a negative relationship with herbs and Rubus cover.

\subsection{Phenotypic plasticity of seedlings}

Many studies taking place in primary or weakly disturbed forests conclude that the degree of phenotypic plasticity for temperate hardwood seedlings is strongly affected by their height (Coleman et al. 1994; Delagrange et al. 2004). We first verified whether this assertion was true for postagricultural forests. The analysis presented in Fig. 4 allows a quantitative assessment of the relative effect of the seedling's environment (light and plant abundance) and its height on seedling morphology. The results confirm the dominant influence of seedling height on seedling morphology in post-agricultural forests. Sugar maple has the strongest relationship, with $31 \%$ of its morphology explained by its height when controlling for the environmental variables (Fig. 4). Black cherry, red maple and ash follow with $21 \%, 17 \%$ and $17 \%$ of morphological variation explained by seedling height, respectively (Fig. 4).
When controlling for plant height, the influence of light and neighbouring plant groups is statistically significant for four out of five species and explains from $4 \%$ to $16 \%$ of the morphological variation. Sugar maple has the highest phenotypic plasticity (16\%), followed by ash $(8 \%)$. Black cherry has a lower phenotypic plasticity $(5 \%)$, whilst the results for red maple are not significant. These trends suggest that levels of plasticity of the studied species could be counterbalanced by their height growth rates.

Significant relationships were found between seedling height and some morphological parameters (Fig. 5). For all species, LAR, SLA and NPT/PT varied significantly with seedling height. The modelled curves applied on the raw data show great differences in the ranges of coefficients of determination $\left(R^{2}\right)$ depending on the morphological variable studied. LAR shows the highest $R^{2}$ ranges (0.28-0.42), NPT/PT is intermediate $(0.11-0.18)$, whilst SLA has the lowest $(0.05-0.09)$. The importance associated with these results should reflect those values. Throughout their vertical development, seedlings increase the relative amount of structural tissue (NPT/PT) over leaf tissue and furthermore reduce the fraction of total leaf surface and thickness relative to other aerial organs of the plant. This reduction of leaf mass and leaf thickness with ontogeny has been noted previously by Walters et al. (1993) in a controlled experiment, although light levels measured in our study were lower than those found in Walters et al. (1993).

Red maple had the lowest SLA and LAR throughout its vertical development, as well as a much higher NPT/PT ratio than any other species. Ash, cherry and sugar maple

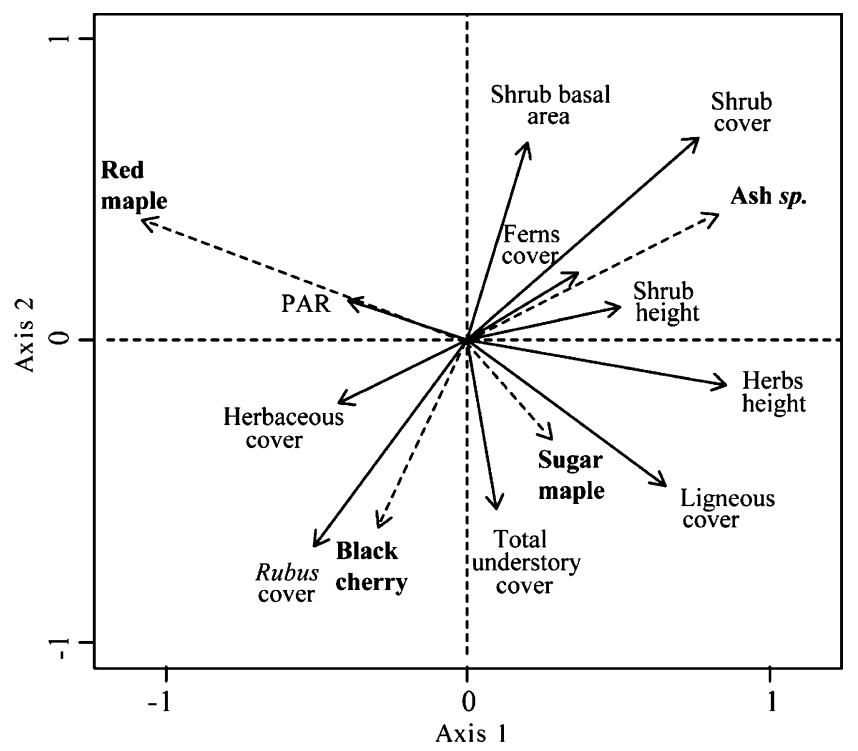

Fig. 3 Correlation biplot of a RDA of seedling species relative annual height growth (dashed arrows) and environmental variables (solid arrows); $F=6.56$ and $p=0.001$ after 9,999 permutations under reduced model. PAR photosynthetically active radiation 


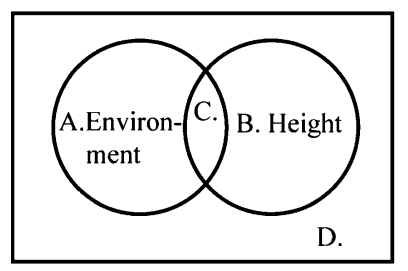

\begin{tabular}{llrcc}
\hline \multicolumn{1}{c}{ Species } & \multicolumn{1}{c}{ A. } & \multicolumn{1}{c}{ C. $^{\mathrm{a}}$} & B. & ABC. \\
\hline Black cherry & $0.05^{* * *}$ & 0.03 & $0.21^{* * *}$ & $0.29 * * *$ \\
Red maple & 0.04 & 0.03 & $0.17 * * *$ & $0.23 * * *$ \\
Sugar maple & $0.16^{*}$ & -0.08 & $0.31^{* * *}$ & $0.38^{* * *}$ \\
Ash sp. & $0.08^{* * *}$ & 0.07 & $0.17 * * *$ & $0.32 * * *$ \\
\hline
\end{tabular}

Fig. 4 Variance partitioning $\left(R^{2}\right)$ and partial RDA of the matrix of morphology variables showing the respective contributions of the environment $(A)$ and of the seedling height $(B)$, their common $(C)$ and combined $(A B C)$ effects. ${ }^{\text {a }}$ The common fraction $(C)$ cannot be tested. Fractions tested on residuals (perm $=9,999$ ). ${ }^{*} p<0.05 ; * * p<0.01 ; * * * p<$

have very similar NPT/PT ratios. Ash species shows slightly higher LAR and SLA, followed by black cherry and sugar maple, suggesting that this species could allocate more energy to its leaves and produce more leaf area per unit mass.

\section{Discussion}

We found strong arguments for the existence of temporal windows of establishment for red maple and black cherry, although sugar maple regeneration does not seem to sustain specific temporal barriers, and ash species shows a series of establishment peaks difficult to categorize. Perhaps the fact that ash is a mix of two distinct species could help explain this result. In fact, a previous study conducted in North eastern USA found clear temporally separated periods of peak individual establishment for white ash (Palik and Pregitzer 1991). It is important to note that species dominating the regeneration layer were sometimes found in the overstory (Table 3). It is probable that they contributed in part to the introduction of seeds on site. However, the clear temporal peaks for black cherry and red maple argue for the existence of some barriers to the survival and growth of the seedlings, although the absence of temporal patterns for ash and sugar maple suggests otherwise. Many studies on old field secondary succession noted that tree invasion was unexpectedly slow (see Myster 1993). They generally explain the establishment delay measured for the second cohort of trees in post-agricultural stands with geographical and physical barriers to species invasion.

Seed-baring red maple, well adapted to many disturbance agents, is becoming more abundant in the landscapes of Eastern North America (Abrams 1998; Brisson and Bouchard 2003). Red maple often dominates the regeneration of secondary forests, although its establishment window varies by region (Peroni 1994; Rankin and Pickett 1989; Zaczek 2002). The invasiveness of black cherry is due in part to a different dispersal mode using birds and mammals-zoochory. It has allowed this species to estab-
0.001; variables included in the environment matrix include PAR ratio as well as plant group height, cover and basal area. Morphology matrix includes GTI, LAR, SLA, H/D and NPT/PT; $D$ represents the unexplained variation of the response data matrix

lish rapidly inside forest patches and agricultural hedgerows of European landscapes. Black cherry is now considered in northwestern Europe (Belgium, the Netherlands, Germany and France) as very invasive (Verheyen et al. 2007). This dispersal mode contrasts with that of red maple whose seeds are dispersed by wind. In its natural habitat (Eastern North America), black cherry specializes in colonizing temperate forest gaps and is abundant in secondary successions (Auclair and Cottam 1971). The results from Phartyal et al. (2009) in Europe show that in stands where the species is abundant in the sapling and tree layer, there is no important seed bank formed in the soil. The same observation was made in North America, as black cherry favours a long-living seedling bank rather than a seed bank (Burns et al. 1990) because its seeds can only remain viable 3 years in the forest floor (Wendel 1977). This strategy is well adapted for the colonization of old fields and young post-agricultural stands because seed banks are usually scarce in old fields except for abandoned pastures. Seedling banks, however, as noted by Phartyal et al. (2009), illustrate a very efficient seed dispersal strategy, and the established seedlings have only to wait for favourable conditions to grow. Two factors could explain the lack of establishment window for sugar maple. First, seeds of sugar maple usually germinate the year following their production, whereas red maple, black cherry or ash seeds remain viable for longer periods of time (Marquis 1975). Second, the strong tolerance of sugar maple to shade and suppression may increase seedling survival after germination.

Although measures of annual height growth rates for seedlings in post-agricultural forests are very scarce, our height growth measures were low compared with other studies. In a Michigan old field dominated by bigtooth and trembling aspen, Palik and Pregitzer (1991) found higher average height growth rates, from 10 to $12 \mathrm{~cm} /$ year for red maple seedlings and from 12 to $20 \mathrm{~cm} /$ year for white ash. They also found no significant difference in height growth between the two species. In a study taking place in southern Quebec, height growth rates for planted 6-year-old black cherry seedlings under a canopy of grey birch were averaging $24.8 \mathrm{~cm} /$ year, whilst height growth rates for 


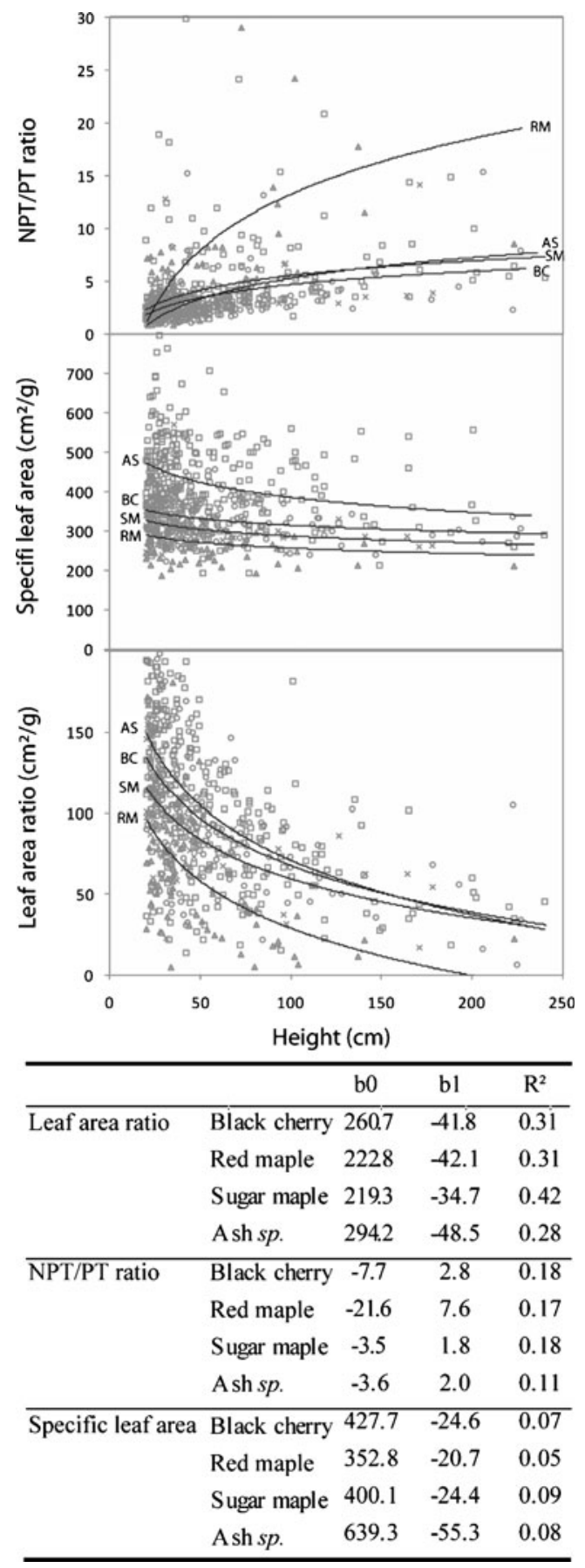

Fig. 5 Morphology of seedling species as a function of height $(H)$. $A S$ ash species (square), BC black cherry (circle), $R M$ red maple (triangle), $S M$ sugar maple (cross), NPT/PT non-photosynthetic tissue over photosynthetic tissue mass ratio. Equations are of the type $Y=b_{0}+b_{1}(H)+\varepsilon$. Only significant relationships are plotted $(\mathrm{p}<0.05)$, with associated parameters given in the inserted table

naturally regenerating sugar maple seedlings were averaging $21.5 \mathrm{~cm} /$ year (Paquette at al. 2007a). The explanations to the general low productivity of the studied species are not within the reach of this study: neither water nor soil nutrients could be measured as both resources could be limiting growth, aside from available light (Burton and Bazzaz 1995). In fact, in a study comparing old field tree establishment in high- and low-fertility sites (Berkowitz et al. 1995), the authors found increased competition levels in high-fertility sites resulting in seedling growth rates similar to unproductive sites. Other stochastic factors such as browsing from white-tailed deer (Odocoileus virginianus) or eastern cottontail (Sylvilagus floridanus) could as well explain part of our results (Côté et al. 2004).

Although all the factors that could explain the growth patterns could not be taken into account, the significant relationships measured between seedling height growth rates and PAR availability generally correspond to the shade tolerance ranks of the five species, with the notable exception of red maple. As Abrams (1998) concluded in a review article on red maple ecology, red maple possesses characteristics of both shade-intolerant and shade-tolerant species. It can persist under very shady environments, whereas it can respond to canopy openings with above average growth rates. The strong negative correlation found between red maple height growth rate and the height of the understory layer confirms its ability to persist in low-light environments. The correlations between black cherry growth and different plant groups could be explained by unmeasured factors such as competition for water or nutrients, although the association with the thorny Rubus genus could give a certain degree of protection from browsing, as was suggested by Paquette et al. (2006) to explain similar results. The results suggest that the levels of available light are not limiting for the very shadetolerant sugar maple. Of all species, sugar maple is represented by the shortest vector on the ordination biplot (Fig. 3), which could mean that it has a higher tolerance to variations in environmental conditions or that the factors affecting its growth have not been taken into account in this study (soil water and nutrients, $\mathrm{pH}$, etc.). Because increases in available understory light favour an important herbaceous cover, ash growth is mostly affected by herbaceous competition. The presence of shrubs and their effect on available light could inhibit the establishment of a highly competitive herbaceous layer (Balandier et al. 2006) and indirectly favour shade-tolerant species such as ash seedlings.

Our results also show no consistent correlation between phenotypic plasticity and shade tolerance, this time because of sugar maple. The accepted theory states that shadetolerant species should show reduced plasticity in order to save resources and tolerate low-light stress (Valladares and Niinemets 2008). Our results rather show that sugar maple is the most plastic of all the studied species. More research is necessary to better understand the link, if any, between phenotypic plasticity and shade tolerance of a species. This information would be extremely helpful for predicting the 
evolution of post-agricultural forests because in the fragmented landscapes where they are found, the enlarging temporal gap between the establishment of earlysuccessional and late-successional species could increase the importance of phenotypic plasticity in the succession of these communities.

We can conclude from these results that sugar maple compensates for its late establishment in post-agricultural forests with greater phenotypic plasticity than the other studied species as it allows the seedlings to maximize their survival in low-light environments. On the opposite, red maple grew best by establishing earlier and allocating more carbon to its ligneous structure compared with all other species, thereby increasing its growth because of higher PAR availability. In exchange, red maple displayed less phenotypic plasticity. Black cherry established quickly in post-agricultural stands, grew faster than ash and sugar maple, and seemed associated positively with certain plant groups such as herbs and Rubus species. As stated earlier, competition for resources not measured here (water or nutrients) could explain such behaviour. Ash is intermediate, showing a relative balance between establishment speed, height growth rate and phenotypic plasticity. Its high abundance in the regeneration layer (see Fig. 1) suggests that this intermediate strategy is also an efficient mean of survival in post-agricultural forest environments.

\section{Conclusion}

Our results show that characteristics associated with shade tolerance ranks of species are not the perfect tool to predict plant succession in post-agricultural forests. Height growth rates of red maple, relative to the other tree species studied, were much higher than expected for a shade-tolerant species, although this species is known to express a changing shade tolerance tributary of its development stage (Coleman et al. 1994). Also, sugar maple showed the highest phenotypic plasticity of all species, whilst shadetolerant species generally tend to tolerate low-light stress by reducing their plasticity to save resources (Valladares and Niinemets 2008).

This study underlines the importance of certain parameters that are specific to post-agricultural contexts to understand their successional dynamic. For example, the isolation of a post-agricultural stand in an agro-forested mosaic generally delays the establishment of later species to the profit of opportunistic species. Indeed, only five species were sufficiently abundant for the needs of this study. Numerous tree species, typical in the study region, were scarce or absent from these communities. Furthermore, we measured low height growth rates that suggest the presence of adverse conditions that could slow down the domination of post-agricultural stands by later successional species. These results militate for the implementation of adapted management strategies for post-agricultural forests in order to restore these abandoned farmlands back into mature forests.

Acknowledgements We thank Danielle Marceau, Marc Delage and Nicolas Soucy-Gonthier for their work on satellite image interpretation. We also thank two anonymous reviewers for their helpful comments. This work was supported by the FQRNT (Action Concertée Fonds Forestier), the PMVRMF (Programme de mise en valeur des ressources du milieu forestier) - Volet II Montérégie to Alain Cogliastro and a grant to the late André Bouchard from the Natural Sciences and Engineering Research Council of Canada.

\section{References}

Abrams MD (1998) The red maple paradox: what explains the widespread expansion of red maple in eastern forests? Bioscience 48:355-364

Auclair AN, Cottam G (1971) Dynamics of black cherry (Prunus serotina Erhr.) in southern Wisconsin oak forests. Ecol Monogr 41:153-177

Balandier P, Collet C, Miller JH, Reynolds PE, Zedaker SM (2006) Designing forest vegetation management strategies based on the mechanisms and dynamics of crop tree competition by neighbouring vegetation. Forestry 79:3-27

Bazzaz FA (1979) The physiological ecology of plant succession. Annu Rev Ecol Syst 10:351-371

Beaudet M, Messier C (1998) Growth and morphological responses of yellow birch, sugar maple, and beech seedlings growing under a natural light gradient. Can J For Res 28:1007-1015

Berkowitz AR, Canham CD, Kelly VR (1995) Competition vs. facilitation of tree seedling growth and survival in early successional communities. Ecology 76:1156-1168

Brisson J, Bouchard A (2003) In the past two centuries, human activities have caused major changes in the tree species composition of southern Québec, Canada. Ecoscience 10:236-246

Burns RM, Honkala BH, Tech. Coords (1990) Silvics of North America: 1. Conifers; 2. Hardwoods. Agriculture Handbook 654, vol. 2. U.S. Department of Agriculture, Forest Service, Washington, DC, $877 \mathrm{pp}$

Burton PJ, Bazzaz FA (1995) Ecophysiological responses of tree seedlings invading different patches of old-field vegetation. J Ecol 83:99-112

Canham CD (1988) An index for understory light levels in and around canopy gaps. Ecology 69:1634-1638

Coleman JS, McConnaughay KDM, Ackerly DD (1994) Interpreting phenotypic variation in plants. Tr Ecol Evol 9:187-191

Côté SD, Rooney TP, Tremblay J-P, Dussault C, Waller DM (2004) Ecological impacts of deer overabundance. Annu Rev Ecol Syst 35:113-147

De Blois S, Bouchard A (1995) Dynamics of Thuja occidentalis in an agricultural landscape of southern Quebec. J Veg Sci 6:531-542

Delagrange S, Messier C, Lechowicz MJ, Dizengremel P (2004) Physiological, morphological and allocational plasticity in understory deciduous trees: importance of plant size and light availability. Tree Physiol 24:775-784

R Development Core Team (2009) R: a language and environment for statistical computing, reference index version 2.9.1. R Foundation for Statistical Computing, Vienna, Austria. ISBN 3-900051-07-0. http://www.R-project.org 
D'Orangeville L, Bouchard A, Cogliastro A (2008) Post-agricultural forests: landscape patterns add to stand-scale factors in causing insufficient hardwood regeneration. For Ecol Manag 255:1637-1646

Englund SR, O'Brien JJ, Clark DB (2000) Evaluation of digital and film hemispherical photography and spherical densiometry for measuring forest light environments. Can J For Res 30:1999-2005

Environment Canada (2004) Climate normals 1971-2000, Canadian Climate Program. Atmospheric Environment Service, Downsview, Ontario

Flinn KM, Vellend M (2005) Recovery of forest plant communities in post-agricultural landscapes. Front Ecol Environ 3:243-250

Gill DS, Marks PL (1991) Tree and shrub seedling colonization of old fields in central New York. Ecol Monogr 61:183-205

Givnish TJ (1988) Adaptation to sun and shade: a whole-plant perspective. Aust J Plant Physiol 15:63-92

Grandtner MM (1966) La végétation forestière du Québec méridional. Presses de l'Université Laval, Québec, 216 pp

Kitajima K (1994) Relative importance of photosynthetic traits and allocation patterns as correlates of seedling shade tolerance. Oecologia 98:419-428

Laplante L (1959) Étude pédologique du Comté de Bagot. Bulletin technique no.6. Ministère de l'agriculture, Sainte-Anne-de-laPocatière, $162 \mathrm{pp}$

Marquis DA (1975) Seed storage and germination under northern hardwood forests. Can J For Res 5:478-484

Meilleur A, Bouchard A, Bergeron Y (1994) The relation between geomorphology and forest community types of the Haut-SaintLaurent, Quebec. Vegetatio 111:173-192

Messier C, Puttonen P (1995) Spatial and temporal variation in the light environment of developing Scots pine stands: the basis of a quick and efficient method of characterizing light. Can J For Res 25:343-354

Myster RW (1993) Tree invasion and establishment in old fields at Hutcheson Memorial Forest. Bot Rev 59:251-272

Niinemets U, Valladares F (2006) Tolerance to shade, drought, and waterlogging of temperate northern hemisphere trees and shrubs. Ecol Monogr 76:521-547

Palik BJ, Pregitzer KS (1991) The relative influence of establishment time and height-growth rate on species vertical stratification during secondary forest succession. Can J For Res 21:1481-1490

Paquette A, Bouchard A, Cogliastro A (2006) Successful under-planting of red oak and blackcherry in early-successional deciduous shelterwoods of North America. Ann For Sci 63:823-831

Paquette A, Bouchard A, Cogliastro A (2007a) Morphological plasticity in seedlings of three deciduous species under shelterwood under-planting management does not correspond to shade tolerance ranks. For Ecol Manag 241:278-287

Paquette A, Bouchard A, Cogliastro A (2007b) A less restrictive technique for the estimation of understory light under variable weather conditions. For Ecol Manag 242:800-804

Peroni PA (1994) Invasion of red maple (Acer rubrum L.) during old field succession in the North Carolina Piedmont: age structure of red maple in young pine stands. B Torrey Bot Club 121:357-359

Phartyal S, Godefroid S, Koedam N (2009) Seed development and germination ecophysiology of the invasive tree Prunus serotina (Rosaceae) in a temperate forest in Western Europe. Plant Ecol 204:285-294

Rankin WT, Pickett STA (1989) Time of establishment of red maple (Acer rubrum) in early oldfield succession. B Torrey Bot Club 116:182-186

Reich PB, Wright IJ, Cavender-Bares J, Craine JM, Oleksyn J, Westoby M, Walters MB (2003) The evolution of plant functional variation: traits, spectra, and strategies. Int J Plant Sci 164:S143-S164

Rowe JS (1972) Les régions forestières du Canada. Publ. n. 1300F, Service canadien des forêts. Ministère de l'environnement, Canada, $172 \mathrm{pp}$

Soucy-Gonthier N, Marceau D, Delage M, Cogliastro A, Domon G, Bouchard A (2003) Détection de l'évolution des superficies forestières en Montérégie entre juin 1999 et août 2002 à partir d'images satellitaires Landsat-Tm. AFM, Institut de Recherche en Biologie Végétale, Montreal, $34 \mathrm{pp}$

Valladares F, Niinemets U (2008) Shade tolerance, a key plant feature of complex nature and consequences. Annu Rev Ecol Evol S $39: 237-257$

Verheyen K, Vanhellemont M, Stock T, Hermy M (2007) Predicting patterns of invasion by black cherry (Prunus serotina Ehrh.) in Flanders (Belgium) and its impact on the forest understorey community. Divers Distrib 13:487-497

Walters MB, Kruger EL, Reich PB (1993) Relative growth rate in relation to physiological and morphological traits for northern hardwood tree seedlings: species, light environment and ontogenetic considerations. Oecologia 96:219-231

Wendel GW (1977) Longevity of black cherry, wild grape, and sassafras seed in the forest floor. USDA Forest Service Res. Paper NE-375, 8 pp

Zaczek JJ (2002) Composition, diversity, and height of tree regeneration, 3 years after soil scarification in a mixed-oak shelterwood. For Ecol Manag 163:205-215 